\title{
PENGEMBANGAN GAME BUBBLE MATCH SEBAGAI MEDIA PEMBELAJARAN PEMBAGIAN DALAM BENTUK PENGURANGAN BERULANG UNTUK SISWA KELAS 2 SD
}

\author{
Meinita Yesi Anugrahini' ${ }^{1}$ Y Y.Windrawanto ${ }^{2}$ \\ Program Studi PGSD FKIP Universitas Kristen Satya Wacana \\ ${ }^{1}$ meinitayess05_@gmail.com; ${ }^{2}$ windrawanto@staff.uksw.edu
}

\begin{abstract}
This study aims to develop bubble match game as a medium of mathematics learning. This research focuses on the division material as a repeat reduction for grade 2 elementary students. Type of research used is Research and Development (RnD) model of ADDIE. The ADDIE development model has stages of Analysis, Design, Implementation and Evaluation. The subjects of this study are 2nd grade students of Elementary School Pangudi Luhur Ambarawa amounted to 37 students. Data collection techniques used are expert test / expert validation, test (multiple choice questions), non test (student response questionnaire and observation sheet). The effectiveness of this media was analyzed using Paired-Samples T Test conducted with SPSS program while the prevalence of media was analyzed using expert test. From this research, it can be concluded that bubble match game media can be developed with ADDIE development model and proven effective with the increase of pretest average 81,62 while posttest 83,24. Media game bubble match proved valid based on validator's judgment from media aspect that got score 4.1 with good category and from material aspect which got average score 3,9 with good category.
\end{abstract}

Keywords: bubble match game, learning media, research and development (RnD)

\section{PENDAHULUAN}

Pendidikan di abad ke-21 menuntut adanya suatu manajemen pendidikan yang modern dan profesional dengan bernuansa pendidikan (Rusman, 2012). Adanya kemajuan dalam dunia ilmu pengetahuan dan teknologi telah membuat pemharuh terhadap penggunaan alat-alat atau media bantu mengajar di sekolah-sekolah dan lembagalembaga pendidikan lainnya.

Dengan kemajuan dalam bidang teknologi, perkembangan pendidikan di sekolah semakin lama semakin mengalami perubahan. Sekarang ini, pembelajaran di sekolah mulai disesuaikan dengan perkembangan teknologi informasi, sehingga terjadi perubahan dan pergeseran paradigma pendidikan. Saat ini banyak media pembelajaran berbantuan komputer digunakan dalam pelajaran, satu diantaranya adalah pembelajaran matematika.

Sebagai ilmu yang universal, matematika mendasari perkembangan teknologi modern , mempunyai peran penting di berbagai disiplin dan memajukan daya pikir manusia. Matematika perlu diajarkan karena pelajaran ini melath siswa untuk berfikir secara logis, analitis, sistematis, kritis, kreatif serta mampu bekerja sama. Jenjang sekolah dasar yang dinilai sebagai pondasi pertama perlu dibangun secara kuat melalui penanaman konsep matematika dan keterampilan yang benar bagi siswa. Pembelajaran matematika di Sekolah Dasar diharapkan dapat menyajikan pembelajaran yang efektif dan efisien sesuai dengan kurikulum dan pola pikir siswa sehingga siswa dapat mudah menyelesaikan masalah matematika yang berkaitan dengan kehidupan sehari-hari 
(Wahyudi dan Kriswandani, 2013). Tujuan pendidikan masa sekarang ialah untuk memberi bekal siswa agar dapat berfungsi secara efektif dalam zaman teknologi.

Namun pada kenyataannya, pembelajaran yang mengantarkan pada peranan tersebut masih menjumpai banyak kendala. Sampai saat ini mata pelajaran matematika masih menjadi mata pelajaran yang dianggap sulit oleh siswa. Dimata siswa matematika merupakan suatu mata pelajaran yang selalu berkaitan dengan angka dan membebani otak dalam berfikir. Kenyataan ini juga diungkapkan oleh (Rusgianto 2006) yang menyatakan bahwa semua tingkatan sekolah ata pendidikan, banyak siswa yang bersikap negatif terhadap matematika, siswa menganggap matematika sebagai bidang studi yang sulit dipelajari, siswa takut terhadap matematika. Tentu saja pandangan atau sikap negatif siswa terhadap matematika berpengaruh terhadap cara-cara siswa dalam mempelajari matematika. Pembelajaran matematika di sekolah dasar faktanya masih belum dikatakan pembelajaran yang efektif dan efisien. Hal ini diperkuat dengan hasil selama melakukan observasi di SD dalam pembelajaran matematika siswa mengalami kesulitan dalam materi dasar matematika contohnya dalam berhitung. Selain hal tersebut Wali Kelas menjumpai kendala yang lain berkaitan dengan pembuatan kegiatan belajar mengajar yang menyenangkan, dikarenakan kurangnya ketersediaan waktu untuk menyediakan media dalam pembelajaran.

Siswa memiliki kecenderungan beradaptasi untuk mendapatkan pendekatan belajar yang sesuai dengan tuntutan di kelas/sekolah maupun tuntutan dari mata pelajaran yang biasa dikenal dengan gaya belajar. Terdapat tiga macam gaya belajar siswa yaitu gaya belajar visual, auditori dan kinestetik (DePorter, 2003). Inilah yang melandasi peneliti mengembangkan suatu media yang sesuai untuk jenis gaya belajar siswa. Pada umumnya guru sekolah dasar hanya membelajarkan matematika dengan cara konvensional, belum memanfaatkan suatu media di dalam pembelajarannya, terutama media yang memanfaatkan teknologi komputer. Pembelajaran matematika yang dilakukan hanya mengharapkan agar materi yang ada cepat selesai sesuai silabus dan hasil nilai yang baik, namun kebermaknaan siswa terhadap suatu pembelajaran menjadi suatu hal yang masih kurang diperhatikan (Arda, 2015).

Penggunaan media akan mempermudah siswa memahami pembelajaran matematika, karena pembelajaran menggunakan media dapat didesain menjadi sebuah pembelajaran yang menarik, menyenangkan sehingga siswa tidak cepat bosan, dan dapat memotivasi serta merangsang siswa untuk semangat dalam belajar, hal ini mendukung tercapainya tujuan pembelajaran yang efektif dan efisien. Penggunaan teknologi pembelajaran yang dapat menggabungkan unsur pendidikan dan unsur hiburan salah satunya adalah digunakannya ilmu teknologi berbasis komputer dalam inovasi model pembelajaran. Darmawan (2012) menyatakan program Computer Assisted Instruction (CAI) model Games atau permainan merupakan program pembelajaran berbantuan komputer yang menekankan pada penyajian bentuk-bentuk permainan dengan muatan bahan pelajaran di dalamnya. Hal ini dibutuhkan agar siswa mampu menerapkan semua pengalaman belajarnya dalam menyelesaikan masalah dan akan termotivasi untuk bermain tanpa menyadari bahwa dia sebenarnya sedang belajar. 
Salah satu program yang bisa digunakan untuk membuat games pembelajaran ini, yaitu menggunakan Adobe flash creative suite 6 . Kelebihan yang dimiliki software ini merupakan program yang didesain khusus oleh Adobe System Incorporated untuk membuat animasi interaktif dan dinamis yang sangat menarik. Adobe flash creative suite 6 didesain untuk membuat animasi flash 2 dimensi yang handal dan ringan bagi sistem perangkat komputer, sehingga bisa dioperasikan tanpa spesikasi komputer yang tinggi. Selain mampu untuk menampilkan multimedia, adalah tersedianya fasilitas untuk memprogram melalui Action Script. Media pembelajaran ini akan dikembangkan dengan model ADDIE (Analysis, Desain, Development, Implementation, Evaliation).

Penelitian yang relevan dengan penelitian ini diantaranya penelitian dari Imam Abdillah dan Dadang Sudrajat 2014. Pengembangan Permainan Ular Tangga pada Pelajaran Matematika untuk Meningkatkan Prestasi Belajar Siswa di SDN Majalengka Wetan VII. Produk dari penelitian ini adalah permainan ular tangga dengan program adobe flash CS 3. Usabilitas dari permainan ini adalah $84,19 \%$, Kompabilitas sebesar 80,15, Interaktivitas sebesar 83,83\%, meningkatkan motivasi belajar sebesar $82,72 \%$, dan tampilan visual dari media sangat menarik yaitu sebesar $81,98 \%$.

\section{Berdasarkan Abror (2003) dalam} penelitiannya tentang Mathematics Adventure Games Berbasis Role Playin Game (RPG) sebagai Media Pembelajaran Mata pelajaran Matematika Kelas VI SD Negeri Jetis 1 menunjukkan tingkat validasi pengembangan media berbasis aplikasi game dari ahli media diproleh nilai rata-rata 4,32 pada kategori sangat layak, ahli materi dipdengan demikian dapat disimpulkan bahwa aplikasi game
"Mathematics Adventure Games" layak digunakan sebagai media karena memperoleh nilai rata-rata 4,34 pada kategori sangat layak.

Penelitian Safitri (2013) yang berjudul "Pengembangan Media Pembelajaran Matematika Pokok Bahasan Segitiga Menggunakan Macromedia Flash Untuk Siswa Kelas VII SMP" berdasarkan hasil dari uji coba diperoleh potensial efek media pembelajaran menggunakan Macromedia Flash terhadap pemahaman konsep siswa yaitu 78 dalam kategori baik. Media pembelajaran ini valid, terlihat dari hasil penilaian validator, dimana semua validator menyatakan baik berdasarkan content, construct dan bahasa. Sedangkan ditinjau dari sisi kepraktisan bahan ajar ini sudah dinyatakan praktis, hal ini terlihat dari hasil uji coba pada one to one dan small group diperoleh rata-rata hasil belajar siswa dalam kategori baik. Berdasarkan filed test diketahui bahwa media ajar interaktif berbasis komputer pokok bahasan segitiga di Sekolah Menengah Pertama memiliki efek potensial terhadap hasil belajar siswa terlihat hasil pencapaian nilai akhir siswa yaitu kategori baik sekali $50 \%$, kategori baik 35\%, sedangkan kategori cukup $12,5 \%$. Sehingga dapat disimpulkan bahwa media pembelajaran berbasis Macromedia Flash pokok bahasan segitiga tersebut efektif digunakan pada pembelajaran matematika.

Berdasarkan analisis yang sudah dilakukan, penulis melakukan pengembangan media pembelajaran berupa game bubble match. Media game bubble match ini memiliki fitur dan kontrol seperti game bubble shooter klasik lainnya, ada sejumlah bubble yang tersedia dan sebuah penembak yang digunakan untuk menghancurkan bubble. Berbeda dengan game yang sudah ada sebelumnya, game ini dikembangkan untuk 
mampu memberikan kondisi lebih rileks yang dirasakan siswa ketika belajar.

Tujuan dari adanya penelitian adalah mengembangkan media pembelajaran matematika game bubble match dalam memahami materi pembagian sebagai pengurangan berulang pada siswa kelas II SD dengan menggunakan model pengembangan ADDIE.

\section{METODE PENELITIAN}

Jenis penelitian yang digunakan penulis adalah penelitian pengembangan dengan model ADDIE yang terdiri dari tahap Analysis, Design, Development, Implementation, dan Evaluation. Penelitian dilaksanakan pada 27-29 Maret 2017 di kelas II SD Pangudi Luhur Ambarawa.

Subjek penelitian ini adalah siswa kelas II SD Pangudi Luhur Ambarawa dengan jumlah 37 siswa. Dalam penelitan ini data diperoleh melalui uji pakar, tes, dan non tes. Uji pakar memiliki tujuan untuk mengetahui kevalidan media pembelajaran game edukasi bubble match. Uji pakar dalam penelitian ini dilakukan melalui uji pakar materi, uji pakar media dan uji pakar soal. Kemudian untuk mengetahui keefektifan produk media pembelajaran game edukasi bubble matc digunakan tes. Sedangkan untuk teknik non tes dilakukan melalui angket dan observasi. Angket digunakan untuk mengetahui kualitas media pembelajaran yang telah diproduksi. Sedangkan observasi dilakukan untuk mengamati bagaimana guru dan siswa melakukan pembelajaran menggunakan media ini.

Lembar validasi pakar dilakukan untuk mengevaluasi media pembelajaran berupa game bubble match. butir penilaian dari aspek materi dan aspek media masing-masing terdiri dari 10 butir. Kategori untuk masing- masing aspek yaitu 1 untuk yang tidak baik dan 5 untuk yang sangat baik. Peneliti membuat rentang skor pada masing-masing kategori dengan cara membuat rentang skor pada masing-masing kategori. Sedangkan untuk validasi pakar soal penilaian dilakukan dengan mencentang kategori valid dan tidak valid untuk masing-masing soal.

Angket respon guru dan angket respon siswa. Angket digunakan untuk mengetahui respon guru dan siswa terhadap implementasi produk yang dikembangkan. bahwa butir penilaian dari angket respon guru terhadap media masing-masing terdiri dari 10 butir. Kategori untuk masing-masing aspek yaitu 1 untuk yang tidak baik dan 5 untuk yang sangat baik. Butir penilaian angket respon siswa media masing-masing terdiri dari 5 butir. Kategori untuk masing-masing aspek yaitu "IYA" dan "TIDAK".

Observasi dilakukan untuk mengamati guru dan siswa dalam penggunaan media game bubble match dalam proses pembelajaran. Kategori untuk masing-masing aspek yaitu 1 untuk yang tidak baik dan 5 untuk yang sangat baik. Tes tertulis digunakan untuk mengetahui keefektifan media pembelajaran yang dikembangkan. Tes tertulis dilaksanakan pada saat pretest dan posttest.

\section{HASIL DAN PEMBAHASAN}

Penelitian ini menghasilkan produk berupa media pembelajaran matematika game bubble match untuk siswa kelas 2 SD pada materi pembagian sebagai pengurangan berulang. Pengembangan ini dilakukan dengan model ADDIE sebagai berikut.

\section{Analisis (Analysis)}

1. Analisis Kurikulum dan Materi 
Kurikulum yang digunakan dalam pengembangan game bubble match adalah kurikulum KTSP. Dalam kurikulum ini terdapat Standart Kompetensi, Kompetensi Dasar dan Indikator (Osman, 2006) dapat dilihat pada Tabel 1.

Tabel 1.

Standart Kompetensi, Kompetensi Dasar dan Indikator

\begin{tabular}{lll}
\hline $\begin{array}{l}\text { Standart } \\
\text { Kompetensi }\end{array}$ & $\begin{array}{l}\text { Kompetensi } \\
\text { Dasar }\end{array}$ & Indikator \\
\hline 3. Melakukan & 3.2. Melakukan & 1.Mengenal \\
perkalian & pembagian & pembagian \\
dan & bilangan dua & sebagai \\
pembagian & angka & pengurangan \\
bilangan & & berulang. \\
sampai dua & & 2.Memecahkan \\
angka. & & masalah sehari- \\
& & hari yang \\
& & melibatkan \\
& & pembagian. \\
\hline
\end{tabular}

Pemetaan yang dilakukan dalam analisis standar kompetensi, kompetensi dasar dan indikator menjadi dasar untuk merancang materi dan kegiatan yang ada di dalam game bubble match.

\section{Analisis Kebutuhan}

Pada tahap ini dilakukan analisis kebutuhan siswa melalui observasi yang dilakukan. Dalam analisis ini didapatkan informasi bahwa masih banyak siswa yang sulit memahami materi matematika, salah satunya adalah pembagian. Kendala yang masih sering ditemui oleh guru dalam pembelajran diantaranya ialah kurangnya ketersediaan waktu untuk membuat pembelajaran yang menarik dan menyenangkan. Akan menjadi lebih baik jika pembelajaran bisa dikemas dengan menarik dan menyenangkan sehingga siswa tidak merasa monoton belajar matematika yang hanya berfikus pada materi dan angka. Kondisi penggunaan media dalam pembelajaran juga masih minim. Guru perlu menyediakan media pembelajaran yang dapat membantu dan memotivasi siswa dalam belajar. Misalnya media-media yang dapat membantu dsiswa dalam memahami materi.

Menanggapi situasi tersebut, maka perlu adanya pengembangan media pembelajaran, khusunya untuk mata pelajaran matematika. Media yang dikembangkan merupakan game yang berisi muatan materi pembelajaran khusunya pembagian sebagai pengurangan berulang. Game yang dikembangkan ini didesain untuk memberikan efek rileks pada anak dalam belajar memahami pembagian sebagai pengurangan berulang.

\section{Perencanaan (Design)}

Media game bubble match dengan materi pembagian sebagai pengurangan berulang, ini disesuaikan dengan kompetensi dasar yaitu melakukan pembagian bilangan dua angka. Maka kompetensi itu menjadi acuan dalam materi yang akan dimuat dalam game bubble match. Metode yang digunakan ialah metode intructional games. Tujuan dari intructional games adalah menyediakan pengalaman belajar siswa dengan memberikan fasilitas belajar untuk menambah kemampuan siswa melalui permainan yang mendidik. Dalam observasi yang dilakukan sekolah memiliki laboratorium komputer, sehingga memungkinkan untuk melaksanakan pembelajaran berbasis komputer.

Media game bubble match yang dikembangkan ini didesain agar siswa dapat memperoleh pengalaman belajar tersebut dengan menyenangkan.

\section{Tahap pengembangan (Development)}

Pada tahap pengembangan dilakukan produksi produk berupa media game bubble match dengan materi pembagian sebagai 


\section{p-ISSN 2406-8012}

pengurangan berulang. Komponen-komponen game bubble match akan diuraikan sebagai berikut.

\section{Animasi Loading}

Animasi loading ini merupakan tampilan awal sebelum masuk pada halaman menu utama game bubble match. Tampilan loading tampak pada Gambar 1.

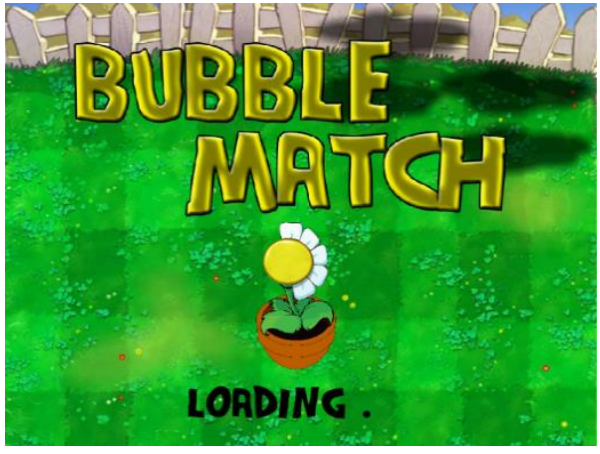

Gambar 1. Tampilan Animasi Loading

\section{Menu Utama}

Tampilan menu utama berisi menu-menu yang ada di dalam game bubble match yaitu about program, direction, playing games, dan help mеnи. Tampilan menu utama dapat dilihat pada gambar 2 berikut.

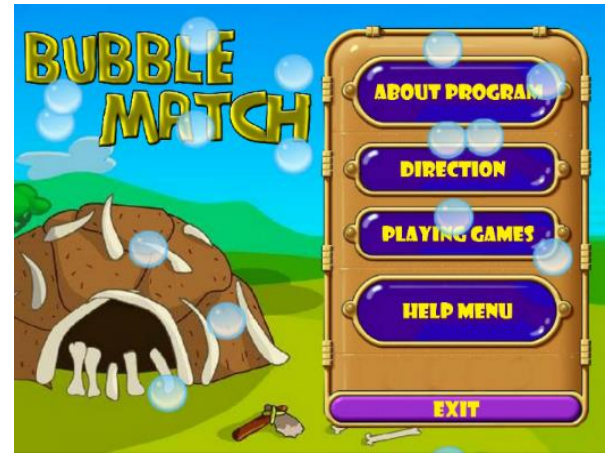

Gambar 2. Tampilan Menu Utama

\section{About program}

Menu about program ini berisi judul pengembangan media, nama peneliti, identifikasi pembelajaran (SK, KD, Materi). Tampilan about program dapat dilihat pada Gambar 3.

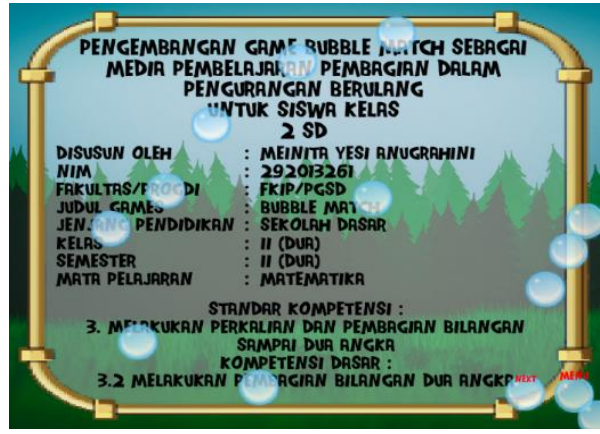

Gambar 3. Tampilan About Program

\section{Direction}

Menu Direction pada media game bubbe match ini berisi petunjuk cara pengoperasian media game buble match. Siswa dapat mempelajari sekilas materi yang harus dipahami sebelum memainkan game. Tampilan Direction tampak pada gambar 4.

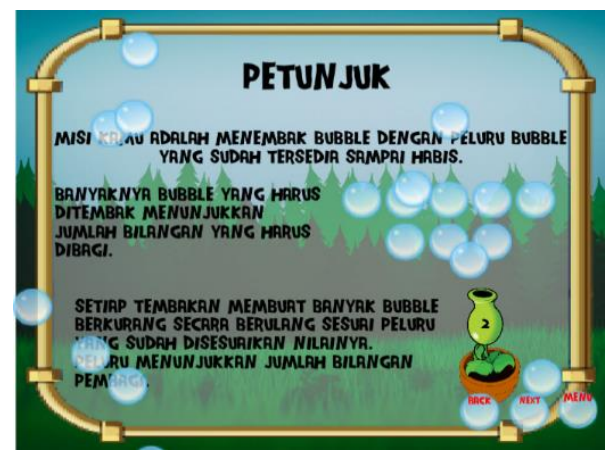

Gambar 4. Tampilan Direction

\section{Playing games}

Pada menu playing games berisi map atau peta permainan yang didalamnya meliputi 5 level yang akan dimainkan dan soal untuk latihan. Untuk masuk dalam permainan siswa memilih level yang akan dimainkan, dalam game ini siswa tidak bisa melompat level, karena untuk melanjutkan ke level berikutnya siswa harus menyelesaikan tiap-tiap level sampai 5selesai. Tampilan 1 playing game dapat dilihat pada Gambar 5. 


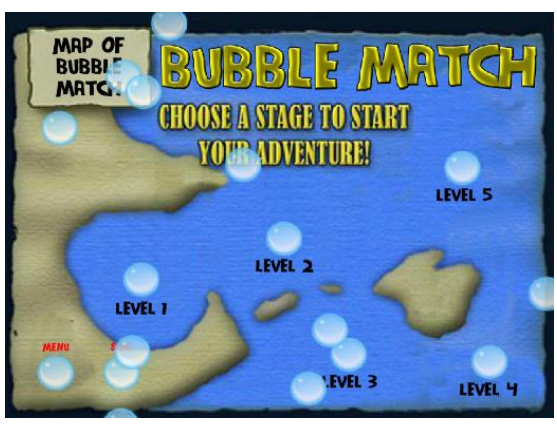

Gambar 5. Tampilan 1 Playing Games

4 Level yang dipilih akan masuk dalam halaman game yang dimainkan. Tampilan ini adalah game bertahan dengan menembak objek yaitu bubble yang jumlahnya sudah ditentukan sebagai bilangan yang harus dibagi dengan cara menembaknya dengan peluru yang sudah ditentukan juga sebagai bilangan pembagi. Setelah berhasil menembak bubble sampai habis pemain harus menjawab pertanyaan dengan benar supaya bisa melanjutkan ke level berikutnya. Jika jawaban salah maka pemain harus mengulangi kembali level yang dimainkan. Tampilan halaman 2 playing games bisa dilihat pada Gambar 6 .

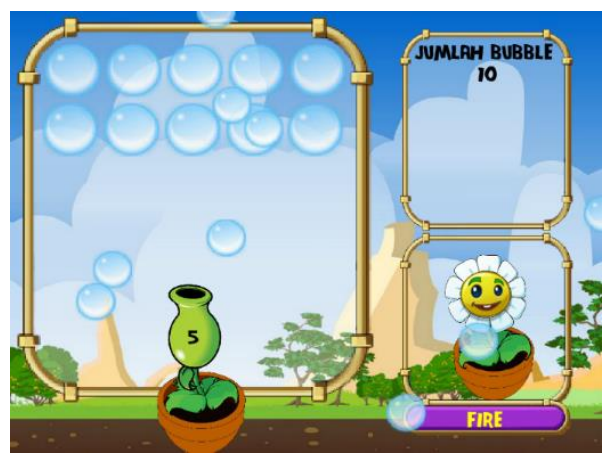

Gambar 6. Tampilan 2 Playing Games

Setelah menyelesaikan 5 level dalam game, secara otomatis akan ditampilkan halaman penguatan yang berisi kesimpulan apa yang sebenarnya dipelajari dari tiap level permainan. Halaman penguatan materi tersebut dapat dilihat pada gambar 7 .

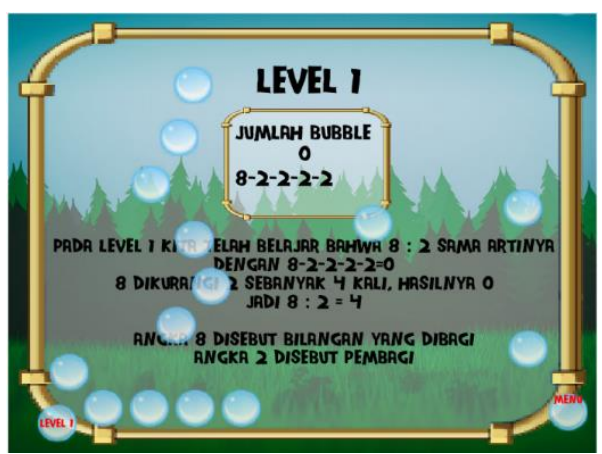

Gambar 7. Tampilan 3 Playing Games

\section{Latihan Soal}

Halaman soal pada media game bubble match ini terdapat pada map atau peta permainan. Halaman ini akan muncul ketika memilih navigasi soal, halaman ini memuat latihan soal yang bisa dikerjakan oleh siswa dan langsung mengetahui nilai hasil latihan soal. Latihan yang terdapat pada halaman soal ada 5 soal isian. Dimana pada halaman ini siswa bisa berlatih secara mandiri. Tampilan halaman soal tampak pada Gambar 8.

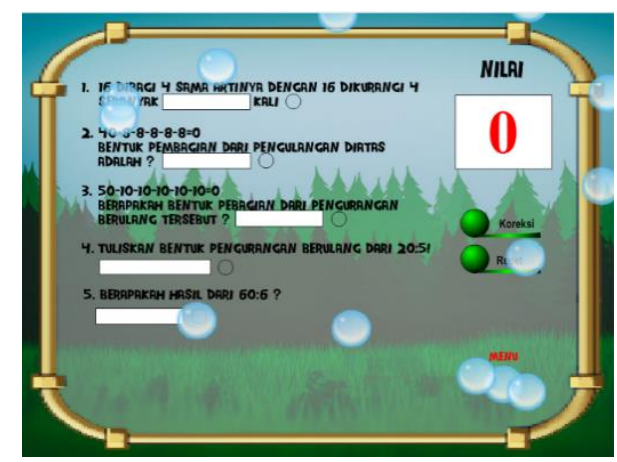

Gambar 8. Tampilan Latihan Soal

\section{Help тепи}

Halaman Help menu berisi penguatan materi dari tiap level yang dimainkan. Isi sama dengan penguatan soal yang muncul otomatis setelah level 5 selesai dimainkan. Pada halaman ini dibahas secara rinci satupersatu apa yang sebenarnya dipelajari pada tiap level. Bahwa tiap level memiliki pembahasan materi yang dimuat pada masingmasing level. Hal ini bisa dimanfaatkan oleh 
guru untuk menjelaskan materi pembagian sebagai pengurangan berulang. Tampilan help тепи dapat dilihat pada gambar 9 .

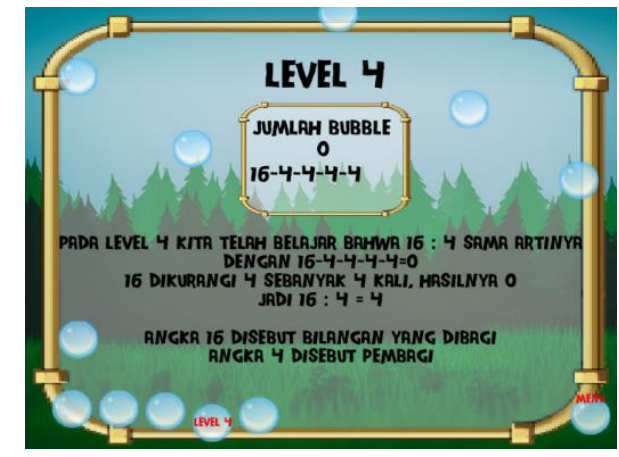

Gambar 9. Tampilan Help Menu

\section{Evaluasi (Evaluation)}

Tahap terakhir pengembangan media game bubble match dengan materi pembagian sebagai pengurangan berulang adalah evaluasi media game bubble match yang sudah dihasilkan dan di uji cobakan.

\section{Analisis Data Kevalidan}

Analisis data kevalidan didapat melalui hasil penilaian validator.. Analisis data kevalidan media game bubble match meliputi hasil validasi pakar media dan pakar materi. Penilaian validator tersebut akan dijelaskan masing-masing sebagai berikut.

Tabel 2. Hasil Validasi Pakar Media

\begin{tabular}{cccl}
\hline No & Indikator & $\begin{array}{c}\text { Rata- } \\
\text { rata }\end{array}$ & Kategori \\
\hline 1 & Media & 4,1 & Baik \\
Rata-rata keseluruhan & 4,1 & Baik \\
\hline
\end{tabular}

Berdasarkan validator pada aspek media diperoleh skor rata-rata 4,1 dengan presentase $82 \%$, menurut kriteria menunjukkan kategori baik.

Tabel 3. Hasil Validasi Pakar Materi

\begin{tabular}{cclc}
\hline No & Indikator & Rata-rata & Kategori \\
\hline 1 & Materi & 3,9 & Baik \\
Rata-rata keseluruhan & 3,9 & Baik \\
\hline
\end{tabular}

Berdasarkan penilaian validator pada aspek materi diperoleh skor 3,9 dengan presentase $78 \%$, kriteria menunjukkan kategori baik.

\section{Analisis Data Keefektifan}

Tabel 4. Hasil Rata-Rata Pretest dan Posttest

\begin{tabular}{lll}
\hline No & Indikator & Rata-rata \\
\hline 1 & Pretest & 81,62 \\
\hline 2 & Posttest & 83,24 \\
\hline
\end{tabular}

Dari analisis data pretest dan posttest diketahui bahwa game bubble match efektif karena adanya peningkatan rata-rata nilai. Angket respon guru yang disediakan terdiri dari 10 indikator. Rata-rata yang diperoeh adalah 39 yang termasuk dalam kategori baik.

Angket yang diberikan kepada siswa terdiri dari 5 indikator. Rata-rata setiap siswa diperoleh isian "YA" dari indikator 1 sampai dengan 5. Dengan demikian menurut hasil angket respon siswa, siswa menyatakan setuju media game bubble match sesuai digunakan dalam proses pembelajaran.

Untuk lembar observasi dari maksimal 40 didapatkan rata-rata 3,87 dengan kategori baik dengan demikian pembelajaran yang dilakukan peneliti sesuai.

\section{SIMPULAN DAN SARAN}

Berdasarkan hasil penelitian dan pembahasan yang telah diuraikan melalui bab sebelumnya, maka diperoleh simpulan produk media pembelajaran game bubble match dapat dikembangkan menggunakan desain pengembangan ADDIE (analysis, design, development, implementation, dan evaluation).

Berdasarkan penelitian yang sudah dilakukan, maka diberikan saran sebagai berikut. 
1. Bagi Siswa

Media game bubble match yang dikembangkan mempermudah siswa dalam memahami materi pembagian khususnya pembagian sebagai pengurangan berulang. Penggunaan media berbasis komputer dengan kemasan permainan dapat menambah minat dan motivasi siswa dalam belajar matematika. Dengan digunakannya media game bubble match peserta didik lebih mandiri dalam belajar serta membuat mereka lebih aktif.

2. Bagi Guru

Penggunaan media game bubble match menjadi salah satu referensi guru untuk memilih media dalam pembelajaran. Media game bubble match ini membantu guru dalam proses pembelajaran. Pada pembelajaran guru bisa menggunakan komputer atau laptop untuk menggunakan media game bubble match.

3. Bagi Sekolah

Pengembangan media game bubble match bisa mendukung pembelajaran berbasis komputer maka sekolah harus menyediakan fasilitas komputer bagi siswa, misalnya dengan penganggaran lab komputer untuk sekolah.

4. Bagi Peneliti Selanjutnya

Pengembangan media game bubble match sebagai media berbasis komputer dapat digunakan untuk materi lainnya. Pengembangan media game bubble match masih sangat luas, kembangkanlah media game pembelajran yang lainnya dengan lebih menarik lagi untuk pembelajaran siswa.

\section{DAFTAR PUSTAKA}

Abror. (2003). Mathematics Adventure Games Berbasis Role Playing Game (RPG) Sebagai Media Pembelajaran Mata Pelajaran Matematika Kelas VI SD Negeri Jetis 1. Disertasi. Yogyakarta: Program Studi Pendidikan Teknik Informatika, Jurusan Pendidikan Teknik Elektronika Fakultas Teknik, Universitas Negerti Yogyakarta

Arda. (2015). Pengembangan Media Pembelajaran Interaktif Berbasis Komputer Untuk Siswa SMP Kelas VIII. e-Jurnal Mitra Sains, Volume 3 Nomor 1, Januari 2015 hlm 69-77.

Darmawan Deni. (2012). Teknologi Pembelajaran. Bandung: PT. Remaja Rosdakarya.

DePorter, Bobbi \& Hernacki. (1999). Quantum Learning. Bandung : Kaifa

Osman. (2006). Matematika kelas 2 Sekolah Dasar. Jakarta: Yudhistira.

Rusman. (2012). Belajar dan Pembelajaran Berbasis Komputer Mengembangkan Profesionalisme Guru Abad 21. Bandung, Alfabeta.

Wahyudi, dan Kriswandani. (2013). Pengembangan Pembelajaran Matematika SD. Salatiga : Widya Sari Press. 